\title{
Tuberous Roots an Ideal System for High Frequency In vitro Regeneration in Plumbago rosea $\mathrm{L}$.
}

\author{
Binoy Jose and K. Satheeshkumar* \\ Biotechnology and Bioinformatics Division, Tropical Botanic Garden and Research \\ Institute, Palode, Thiruvananthapura-695 562, India
}

Key words: Plumbago rosea, Tuberous root, Multiple shoots, High frequency

\begin{abstract}
Tuberous root explants of Plumbago rosea L. cultured in MS containing $3.5 \mathrm{mg} / \mathrm{l}$ BAP showed high frequency of shoot bud regeneration $(62.33 \pm 0.66 ; 0.26 \pm 0.07$ $\mathrm{cm})$ within eight weeks. Subculture of shoot clumps (22.17 \pm 0.90 shoots; $0.26 \pm$ $0.07 \mathrm{~cm}$ ) from the initial clump exhibited extensive rate of shoot multiplication $(123.4 \pm 1.029$ shoots, $0.22 \pm 0.01 \mathrm{~cm})$ per each clump and produced a total of 369 shoots in $3.5 \mathrm{mg} / \mathrm{l} \mathrm{BAP}$ in six weeks. Within two weeks of culture in basal liquid medium, shoot elongation $(6.16 \pm 0.14 \mathrm{~cm})$ occurred and after three weeks in MS solid medium supplemented with $0.1 \mathrm{mg} / \mathrm{l} \mathrm{IAA}$, rooting $(14.7 \pm 1.2)$ initiated on the shoots. Ninety six per cent of the rooted plants were established under the shade nethouse with regular watering.
\end{abstract}

\section{Introduction}

Tuberous roots of Plumbago rosea L. (Plumbaginaceae) - an important medicinal plant of tropical India, find extensive use in a variety of ayurvedic preparations intended for the treatment of various ailments such as leucoderma, secondary syphilis, intestinal worms and several skin diseases. The plant has become rare in several parts of India (Chetia and Handique 2000) due to its endemic nature (Komaraiah et al. 2004), the absence of seed set (NISCAIR 1989), slow vegetative propagation and its frequent harvest by local tribes or pharmaceutical companies for the roots (Komaraiah et al. 2004).

Plumbagin (5-hydroxy 2-methyl 1, 4-naphthoquinone) forms a chief ingredient $(0.9-1 \%)$ in the tuberous roots and displays a wide range of pharmacological activities including radio sensitizing (Nair et al. 2007), antioxidant (Tilak et al. 2004), anti malarial (Likhitwitayawuid et al. 1998) etc. It is also a potential anticancer agent (Parimala and Sachdanandam 1993) which selectively acts on cancer cells without damaging normal epithelial, lung or cervical cells and this makes it highly prospective of being developed as a substantial anticancer drug (Nazeem et al. 2009). This root specific metabolite is

*Author for correspondence: <bioproduction09@@gmail.com>. 
acquired solely from tuberous roots of the plants though several other plumbagin producing systems such as normal and hairy root cultures have been established (Panichayupakaranant and Tewtrakul 2005; Gangopadhyaya et al. 2008). Reports ascertain that cultivated micropropagated plants give better root biomass and plumbagin yield within a shorter time as compared to the conventionally propagated plants (Satheeshkumar and Seeni 2003). This study is the first attempt to use tuberous roots as explant to investigate whether a high frequency regeneration and multiplication protocol can be established.

\section{Materials and Methods}

Explants were collected from the tuberous roots $(7-8 \mathrm{~cm}$ length, $0.5 \mathrm{~cm}$ dia) from one year old Plumbago rosea L. grown in the medicinal garden of TBGRI (The voucher specimen deposited at the Institute Herbarium TBGT, under reference number 3129). They were first washed thoroughly under running tap water (15 $\mathrm{m})$, then with $(0.1 \% \mathrm{v} / \mathrm{v})$ aqueous surfactant Teepol (BDH, India) $(15 \mathrm{~m})$ and then repeatedly rinsed with distilled water. Further sterilization was done under aseptic conditions in a laminar airflow (Klenzaid, India). The root surface wiped with absorbent cotton swab dipped in $70 \%(\mathrm{v} / \mathrm{v})$ ethyl alcohol, cut into segments of appropriate size $(1.5-2.0 \mathrm{~cm})$ and surface sterilized with $0.1 \% \mathrm{HgCl}_{2}$ for six min followed by three washes in sterile distilled water. Cut ends of the treated explants were removed before vertical inoculation into culture bottles $(11 \times 6 \mathrm{~cm})$ containing $30 \mathrm{ml}$ MS supplemented with different concentrations of BAP (0.5 $4.0 \mathrm{mg} / \mathrm{l}), \mathrm{Kn}(0.5-4.0 \mathrm{mg} / \mathrm{l})$ and combinations of BAP $(1.5-3.5 \mathrm{mg} / \mathrm{l})$ with IAA $(0.5-1.0 \mathrm{mg} / \mathrm{l})$ were used. The $\mathrm{pH}$ of the media was adjusted to 5.8 before adding agar $6 \%(\mathrm{w} / \mathrm{v})$ and autoclaved at $121^{\circ} \mathrm{C}$ for $18 \mathrm{~min}$. The cultures were incubated at $24^{\circ} \mathrm{C} \pm 2$ in $30-35 \mu \mathrm{E} / \mathrm{m}^{2} / \mathrm{s}$ intensity of white fluorescent light. Shoot initiation on explants was detected by observing the cross section of the explants stained with safronin under a binocular microscope (Leica 20, Germany).

Multiple shoots formed in the initial medium were longitudinally split into clumps with an average of $22.17 \pm 0.90$ shoots $(0.2-0.6 \mathrm{~cm}$ long) and transferred to media supplemented with $1.0-5.0 \mathrm{mg} / \mathrm{l}$ BAP for further multiplication. After six weeks, shoots (Av. 15 - 20/clump) $0.2-1.0 \mathrm{~cm}$ long were cut from the multiplication medium and transferred to liquid medium for elongation. After two weeks, elongated shoots of $5-6 \mathrm{~cm}$ length were separated and transferred on to MS or supplemented with IBA $(0.1-0.5 \mathrm{mg} / \mathrm{l})$ for rooting. The well rooted shoots were deflasked after three weeks, gently washed and planted in pots (10 inches size) containing soil and sand $(1: 1)$. The plantlets were kept in the shade nethouse provided with $50 \%$ shade and watered regularly. Each treatment consisted of 10 replicates and the whole experiment was conducted twice for 
confirmation. The data was subjected to ANOVA and the mean values of different treatments compared using DMRT.

\section{Results and Discussion}

Despite culture initiation using tuberous roots that are more prone to soil microbes, $80 \%$ contamination free explants were significantly higher than nodal explants (Chetia and Handique 2000, Jose et al. 2007). However, reduced contamination rate recorded here might be due to the remarkable influence of the antimicrobial (Ribeiro et al. 2003) secondary metabolite (plumbagin) released from the cut ends of the root segments. Shoots initiated only after two passages of explants to fresh medium at an interval of 10 days as there was problem of leaching of the yellow pigment into the medium. Delayed shoot morphogenesis due to the leaching of phenols or other secondary compounds to the medium from the explants is common in many taxa including medicinal plants. Root explants responded readily after two passages by generating small protuberances irrespective of whether the media contained hormones or not. Shoot morphogenesis was noticed on the surface of root segments in a period of four weeks (Fig. 1). Shoot regenerated also in media devoid of hormones but it was delayed up to five weeks. Explants produced shoot buds along with semifriable callus in media supplemented with combinations of BAP, Kn and IAA (Table 1).

Shoot bud formation was not preceded by callusing and it was confirmed through the anatomical observation that the shoot differentiation was from the sub-epidermal tissue (Fig. 2). During continuous incubation of the explants in the same medium for a period of eight weeks, shoot proliferation spreaded throughout the surface of the explants and $62.33 \pm 0.66$ shoots were obtained (Fig. 3). Shoot proliferation continued till the exhaust of the medium (ten weeks) and the shoot buds thus produced were very healthy.

Multiplication of shoots was further enhanced by the subculture of shoot clumps $(22.17 \pm 0.90$ shoots $(0.2-0.6 \mathrm{~cm}$ long $)$ into media containing varied concentrations of BAP $(1.0-5.0 \mathrm{mg} / \mathrm{l})$ and an average of $123.4 \pm 1.029$. Shoots per clump were obtained in a period of six weeks (Fig. 4, Table 2). Along with multiplication, nearly $20 \%$ of the shoots exhibited elongation $(1.2-2.6 \mathrm{~cm})$. After six weeks, these clusters of shoots were again cut and transferred to the medium containing 3.0 or $3.5 \mathrm{mg} / \mathrm{l} \mathrm{BAP}$ for further shoot proliferation to enhance shoot production. Direct shoot proliferation was restricted and nodular type regenerative callus formation was noticed during repeated subculture in media containing more than $3.5 \mathrm{mg} / \mathrm{l}$ BAP. Shoot bud regeneration during multiplication was from the base of each shoot and it continued till the medium got exhausted after ten weeks. It was interesting to observe that the frequency of 
shoot bud proliferation in root explants was much higher compared to other explants tried earlier (Jose et al. 2007). The inherent quality of roots which makes them a better choice for vegetative propagation and the

Table1. Shoot regeneration on field derived tuberous roots of $P$. rosea. Observations were taken after eight weeks.

\begin{tabular}{|c|c|c|c|c|c|}
\hline \multicolumn{3}{|c|}{ PGRs (mg/l) } & \multirow{2}{*}{$\begin{array}{l}\text { Number of } \\
\text { shoots/root }\end{array}$} & \multirow{2}{*}{$\begin{array}{l}\text { Length of shoot } \\
\text { buds }(\mathrm{cm})\end{array}$} & \multirow{2}{*}{$\begin{array}{l}\text { Degree of } \\
\text { callusing }\end{array}$} \\
\hline BAP & $\mathrm{Kn}$ & IAA & & & \\
\hline 0 & 0 & 0 & $3 \pm 0.31 d$ & $0.64 \pm 0.09 a$ & \\
\hline 0.5 & 0 & 0 & $8.5 \pm 0.73 d$ & $0.575 \pm 0.047 a$ & \\
\hline 1 & 0 & 0 & $15.2 \pm 0.73 c$ & $0.35 \pm 0.076 a$ & \\
\hline 2 & 0 & 0 & $25.5 \pm 0.96 b$ & $0.26 \pm 0.02 \mathrm{ba}$ & \\
\hline 3 & 0 & 0 & $34.7 \pm 0.85 b$ & $0.23 \pm 0.01 \mathrm{ba}$ & \\
\hline 3.5 & 0 & 0 & $62.33 \pm 0.66 a$ & $0.26 \pm 0.07 \mathrm{~b}$ & \\
\hline 4.0 & 0 & 0 & $31.2 \pm 0.58 b$ & $0.22 \pm 0.06 \mathrm{ba}$ & + \\
\hline 0 & 0.5 & 0 & $5.0 \pm 0.41 d$ & $0.52 \pm 0.13 a$ & \\
\hline 0 & 1.0 & 0 & $7.5 \pm 1.7 \mathrm{~d}$ & $0.5 \pm 0.10 \mathrm{a}$ & \\
\hline 0 & 2.0 & 0 & $11.5 \pm 0.96 \mathrm{~d}$ & $0.45 \pm 0.06 a$ & \\
\hline 0 & 3.0 & 0 & $13.0 \pm 1.29 \mathrm{c}$ & $0.46 \pm 0.08 a$ & \\
\hline 0 & 3.5 & 0 & $22.7 \pm 1.7 \mathrm{c}$ & $0.37 \pm 0.14 a$ & \\
\hline 0 & 4.0 & 0 & $15.0 \pm 1.4 \mathrm{c}$ & $0.34 \pm 0.08 \mathrm{a}$ & + \\
\hline 1.5 & 0 & 0.5 & $3.5 \pm 0.64 \mathrm{~d}$ & $0.6 \pm 0.07 a$ & ++ \\
\hline 2.5 & 0 & 1 & $7.8 \pm 2.3 \mathrm{~d}$ & $0.13 \pm 0.03 \mathrm{ba}$ & ++ \\
\hline 3.5 & 0 & 1 & $3.5 \pm 0.64 \mathrm{~d}$ & $0.12 \pm 0.02 \mathrm{ba}$ & ++ \\
\hline
\end{tabular}

'+' indicates degree of callusing. Means followed by different letters significantly differed at $5 \%$ level.

Table 2. Shoot multiplication through subculture of shoot clumps $(22.17 \pm 0.90)$ obtained from tuberous root explants. Observations were taken after six weeks.

\begin{tabular}{lccc}
\hline $\begin{array}{l}\text { BAP } \\
(\mathrm{mg} / \mathrm{l})\end{array}$ & $\begin{array}{c}\text { Average No. of } \\
\text { shoots in clumps }\end{array}$ & $\begin{array}{c}\text { Length of shoots } \\
(\mathrm{cm})\end{array}$ & $\begin{array}{c}\text { Degree of } \\
\text { callusing }\end{array}$ \\
\hline 1.0 & $56.4 \pm 1.7 \mathrm{~d}$ & $1.02 \pm 0.10 \mathrm{a}$ & - \\
2.0 & $79.2 \pm 8.21 \mathrm{c}$ & $0.63 \pm 0.038 \mathrm{a}$ & - \\
3.0 & $115.2 \pm 1.7 \mathrm{a}$ & $0.35 \pm 0.02 \mathrm{~b}$ & + \\
3.5 & $123.4 \pm 1.02 \mathrm{a}$ & $0.22 \pm 0.01 \mathrm{~b}$ & ++ \\
4.0 & $120 \pm 0.70 \mathrm{a}$ & $0.34 \pm 0.021 \mathrm{~b}$ & +++ \\
5.0 & $105.6 \pm 2.61 \mathrm{~b}$ & $0.24 \pm 0.06 \mathrm{~b}$ & +++ \\
\hline
\end{tabular}

' + ' indicates degree of callusing; '-' indicates no callus induction. Means followed by different letters within the columns significantly differed at $5 \%$ level.

augmenting influence of enriched nutrients supplied in the media, together substantiate the remarkable regeneration potential of the tuberous root explants. While testing the regeneration potential of the root explants in media 
supplemented with hormones individually or in combination of auxins and cytokinins did not exhibit much difference but callus formation was prominent (Data not presented).

Eighty five per cent of shoots in the shoot cluster transferred to liquid medium elongated up to $5-6 \mathrm{~cm}$ in a span of two weeks. The elongated shoots transferred to the MS agar medium containing IBA were rooted and maximum root formation $(14.7 \pm 1.2)$ was obtained in $0.1 \mathrm{mg} / \mathrm{l} \mathrm{IBA}$. Rooting response in shoot buds was corresponding to the previous reports and there was no significant difference observed in plants irrespective of the explant source (Chetia and Handique 2000, Satheeshkumar and Seeni 2003). The rooted plants transferred to pots recorded $96 \%$ establishment under the shade net house with regular watering (Fig. 5).
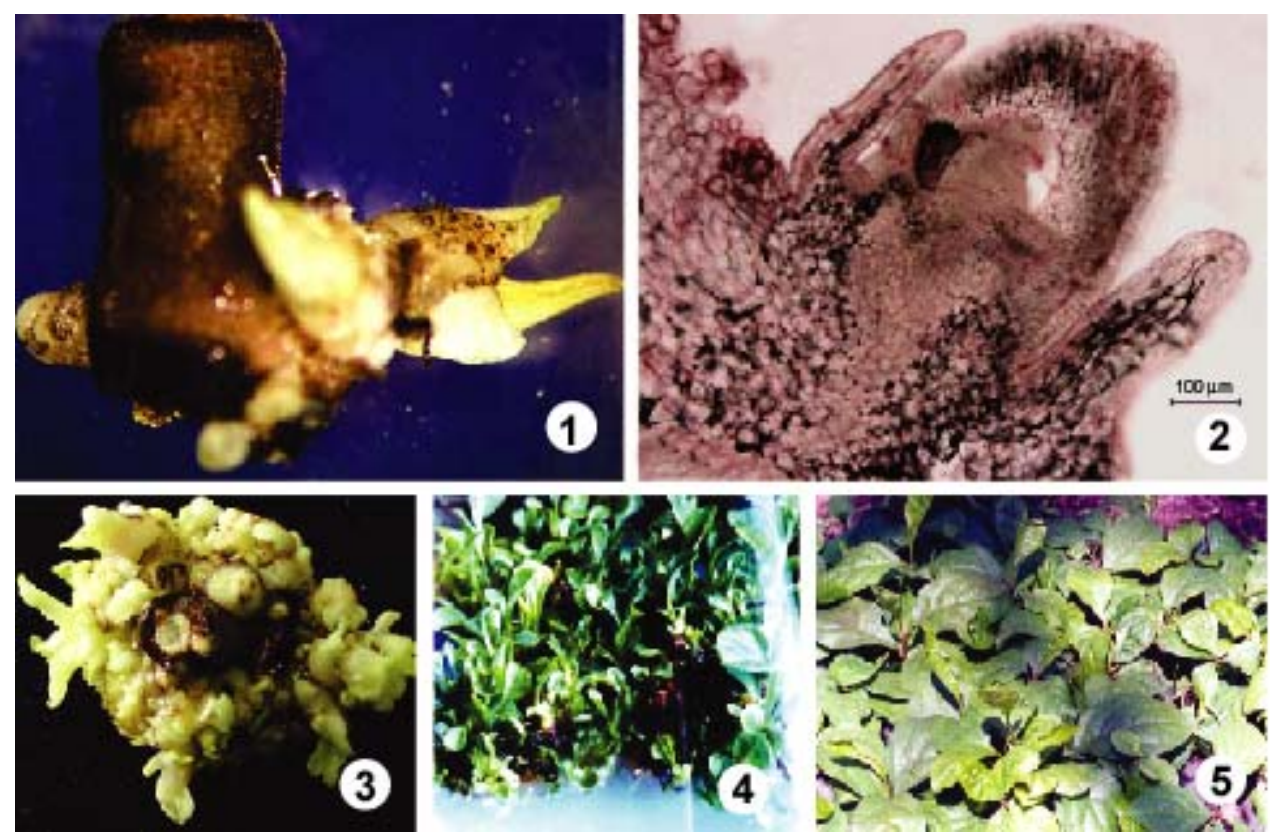

Figs 1-5. 1. Multiple shoots initiated on tuberous root explants on MS supplemented with $3.5 \mathrm{mg} / \mathrm{l} \mathrm{BAP}$ after four weeks. 2. Cross section (CS) of the root explants with shoot primordia. 3. Shoot proliferation on tuberous root explants. 4. Multiple shoots produced by subculture of shoot clumps. 5. Plants established in polybags.

The number of healthy shoot buds obtained on tuberous root explants in the present study is much higher than those reported earlier with nodal explants (Harikrishnan and Hariharan 1996, Chetia and Handique 2000, Jose et al. 2007). Large surface area $(0.4-0.5 \mathrm{~cm}$ diam) of the root segment and major portion of the tissues in contact with the media including enhanced meristematic activities 
of the root cells are the main factors that contributed to the high frequency shoot formation recorded here, which is virtually absent in nodal segments wherein direct shoot proliferation is limited only on resident axillary meristems.

Table 3. Comparative data of published reports on direct multiple shoot formation in $P$. rosea reported with the present data on tuberous root explants.

\begin{tabular}{|c|c|c|c|c|c|c|}
\hline Explants & $\begin{array}{l}\text { No. of shoot } \\
\text { buds initiated } \\
\text { (period) }\end{array}$ & $\begin{array}{c}\text { Mode of } \\
\text { subculture }\end{array}$ & $\begin{array}{c}\text { Multiple } \\
\text { shoots (period) }\end{array}$ & $\begin{array}{c}\text { Media used } \\
\text { (hormones } \\
\mathrm{mg} / \mathrm{l} \text { ) }\end{array}$ & $\begin{array}{c}\text { Av. shoots } \\
\text { obtained/ } \\
\text { week }\end{array}$ & References \\
\hline Node & $\begin{array}{c}22.5 \pm 1.70 \\
\text { (five weeks) }\end{array}$ & $\begin{array}{l}\text { No data } \\
\text { available }\end{array}$ & $\begin{array}{l}\text { No data } \\
\text { available }\end{array}$ & $\begin{array}{c}\mathrm{MS}+1.5 \\
\mathrm{BAP}+0.5 \\
\mathrm{IAA}\end{array}$ & 4.6 & $\begin{array}{l}\text { Harikrishnan } \\
\text { and Hariharan } \\
1996\end{array}$ \\
\hline Node & $\begin{array}{l}\text { Small buds } \\
\text { (four weeks) }\end{array}$ & $\begin{array}{l}\text { Explant with } \\
\text { shoot buds }\end{array}$ & $\begin{array}{c}35 \\
\text { (four weeks) }\end{array}$ & $\begin{array}{c}\mathrm{MS}+3 \mathrm{BAP} \\
25 \mathrm{AS}\end{array}$ & 4.42 & $\begin{array}{l}\text { Chetia and } \\
\text { Handique } 2000\end{array}$ \\
\hline Node & $\begin{array}{c}2.41 \pm 0.14 \\
\text { (three weeks) }\end{array}$ & $"$ & $\begin{array}{c}42.1 \pm 5.4 \\
\text { (three weeks) }\end{array}$ & $\begin{array}{c}\mathrm{MS}+3.5 \\
\mathrm{BAP}\end{array}$ & 7.01 & Jose et al. 2007 \\
\hline $\begin{array}{l}\text { Tuberous } \\
\text { root }\end{array}$ & $\begin{array}{c}62.33 \\
\text { (eight week) }\end{array}$ & $"$ & $\begin{array}{c}369 \\
\text { (six weeks) }\end{array}$ & $\begin{array}{c}\mathrm{MS}+3.5 \\
\mathrm{BAP}\end{array}$ & 26.3 & Present data \\
\hline
\end{tabular}

Altogether 369 shoots were produced from a single root explant of $1.0 \mathrm{~cm}$ long in a period of 14 weeks. Mass multiplication protocol developed using tuberous root explants in the present study shows remarkable difference with that of the earlier reports in $P$. rosea with regard to the frequency of direct shoot regeneration. Although the bud formation in tuberous root explants was delayed up to eight weeks, the frequency of bud initiation was higher than that of the nodal explants and the rate of shoot multiplication was also recorded top to be high in the tuberous root explants compared to nodal segments described elsewhere (Table 3). The overall results indicate the totipotent behavior of the root cells and suitability of the system for large scale production of healthy planting materials.

\section{Acknowledgement}

This paper is a part of a Ph. D. thesis of the first author (BJ) to Kannur University, Kannur, India. The authors are grateful to the Director of TBGRI for providing the facilities for the study.

\section{References}

Chetia S and Handique PJ (2000) High frequency in vitro multiplication of Plumbago indica, a medicinal plant. Curr. Sci. 78: 1187. 
Gangopadhyaya M, Sircar D, Mitra A and Bhattacharya S (2008) Hairy root culture of Plumbago indica as a potential source for plumbagin. Biol. Plant. 52: 533-537.

Harikrishnan KN and Molly Hariharan (1996) Direct Shoot regeneration from nodal explants of Plumbago rosea L. - A Medicinal plant. Phytomorphology 46: 53-58.

Jose B, Satheeshkumar K and Seeni S (2007) A protocol for high frequency regeneration through nodal explant cultures and ex vitro rooting of Plumbago rosea L. Pak. J. Biol. Sci. 10: 349-355.

Komaraiah P, Jogeswar G, Ramakrishna SV and Kavi Kishor PB (2004) Acetylsalicylic acid and ammonium-induced somatic embryogenesis and enhanced plumbagin production in suspension cultures of Plumbago rosea L. In Vitro Cell Dev. Biol. Plant 40: $230-234$.

Likhitwitayawuid K, Kaewamatawong R, Ruangrungsi N and Krungkrai J (1998) Antimalarial naphthoquinones from Nepenthes thorelii. Planta Med. 64: 237-241.

Nair S, Nair RR, Srinivas P, Srinivas G and Pillai MR (2007) Radiosensitizing effects of plumbagin in cervical cancer cells is through modulation of apoptotic pathway Mol. Carcinog 47: 22-33.

Nazeem S, Azmi AS, Hanif S, Ahmad A, Mohammad RM, Hadi SM and Kumar KS (2009) Plumbagin induces cell death through a copper-redox cycle mechanism in human cancer cells. Mutagenesis. pp. 1-6.

NISCAIR (1989) In: The Wealth of India A Dictionary of Indian Raw Materials and Industrial Products, Vol. II (Council of Scientific Industrial Research, New Delhi, India). p. 163.

Parimala R and Sachdanandam P (1993) Effect of plumbagin on some glucose metabolizing enzymes studied in rats in experimental hepatoma. Mol. Cell Biochem. 12: 59-63.

Panichayupakaranant P and Tewtrakul S (2005) Plumbagin production by root cultures of Plumbago rosea, Electronic Journal of Biotechnology [online] 15 December 2005, 5(3). Available from: http://www.ejbiotechnology.info/content/vol5/issue3/full /3/ index. html. ISSN 0717-3458.

Ribeiro SP, Raquel MF and Verônica TA (2003) Auxiliadora, M.C.K. Antimicrobial activity in vitro of plumbagin isolated from Plumbago species. Mem. Inst. Oswaldo Cruz 98: 959-961.

Satheeshkumar K and Seeni S (2003) In vitro mass multiplication and production of roots in Plumbago rosea. Planta Med. 69: 83-86.

Tilak JC, Adhikari S and Devasagayam TPA (2004) Antioxidant properties of Plumbago zeylanica, an Indian medicinal plant and its active ingredient, plumbagin. Redox. Rep. 9: 219-227. 